\title{
Gender and Sexual Identity in Arundhati Roy's The Ministry of Utmost Happiness: A Cixousian Analysis of Hijra's Resistance and Remaking of the Self
}

\author{
Nur Ain Nasuha Binti Anuar and Moussa Pourya Ası* \\ English Language Studies Section, School of Humanities, Universiti Sains Malaysia, 11800 USM, Gelugor, \\ Penang, Malaysia
}

\begin{abstract}
Hijra is a distinctive South Asia known for their gender and sexual difference and associated with their transgender and intersex identities. Otherwise known as transwomen, they are traditionally subjected to prejudices and embedded within narratives of exclusion, discrimination, and the subculture. As a result, Hijras are typically perceived as isolated, abject, and passive victims who remain social and economic peripheries. Concerning the stereotypical image of hijras, this study explores Arundhati Roy's The Ministry of Utmost Happiness (2017) to examine the novel's problematization of hijras in India. In this novel, sexual and gender non-conformity are addressed within characters desiring to be neither a man nor a woman. Drawing on Hélène Cixous's theories of inherent bisexuality and ecriture féminine, this study examines characters' contestations and alterations of existing definitions of sex and gender. This framework allows for a manifestation of gender flexibility and feminine writing as a tool for self-emancipation. Both protagonists Anjum and Tilo, illustrate that hijras are not predetermined but are formulated in a complex process of a conscious rewriting of the self. While the former character resists heteropatriarchal normativity through her conscious alterations of the phallogocentric structure of her Urdu language, the latter defies societal conventions of family and marriage with unorthodox views and actions that are materialized in the writing of her story.
\end{abstract}

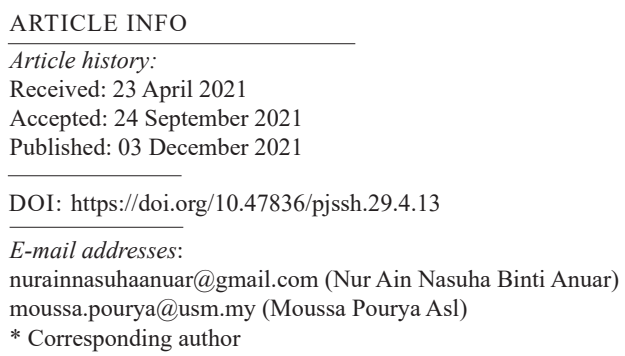

Keywords: Écriture féminine, hijra, identity formation, inherent bisexuality, resistance

\section{INTRODUCTION}

Hijra is a distinctive South Asia known for their gender and sexual difference and associated with their transgender and intersex identities. Despite recent socio- 
cultural developments in legal recognition and public reception of the community as the third gender, hijras or transwomen remain on the fringes of Indian society. Historically, hijrahood is associated with discourses of exclusion, discrimination, and the subculture, traditionally subjected to various prejudices and intolerance. The identity of a hijra is thus perceived to be that of an isolated, abject, and passive victim who is excluded from mainstream social and economic life. Over the past two decades, the growing number of ethnographic studies about hijras in India have reinforced the stereotypical image of the community (Hossain, 2012; Iesar, 2019; Islam, 2020; Lau \& Mendes, 2019; Mendes \& Lau, 2020; Menozzi, 2019). Relatively scant attention has been given to the active struggles of individual members of this community in realizing self and elevating their social status.

The present study focuses on the literary representation of hijras to underline individual and collective ways in which the community members redefine self by liberating themselves from the shackles of phallogocentrism of language. Arundhati Roy's The Ministry of Utmost Happiness (2017; hereafter, TMOUH) problematizes the heteropatriarchal definitions of sex and gender through the two leading characters of Anjum and Tilo. Both characters react against the dominant perception of gender and sexual difference by rejecting patriarchy and struggling to redefine and reassert their identities. To pursue the argument, this study employs the poststructuralist feminist Hélène Cixous's notions of inherent bisexuality and écriture féminine that uplift feminine subjectivity as a necessary component in understanding the subtle nuances of identity politics as depicted in the novel.

Cixous (1976) describes "other bisexuality" as having the qualities of "the feminine" and "the other" constituent elements. "The feminine" and "the other" allow for a manifestation of gender flexibility by rejecting the universalized and objectified discourse of a masculine-feminine dichotomy (Blades, 2009). Moreover, écriture féminine or feminine writing serves to release and materialize "the feminine" and "the other" into consciousness. It celebrates sexual difference by deconstructing and reconstructing the markings of women as negative and absent "and bring[ing] out a positiveness which might be called the living other" (Cixous, 1981, p. 50). The notion of écriture féminine encourages women's writing of the body and of their personal story as a strategy to legitimize their existence against the traditional male-centric writing (Hoctor, 2013). From a Cixousian perspective, the potential to embody "the feminine" and "the other" with inherent bisexuality catalyze the emergence of feminine writing as a tool for self-emancipation where such potential can be realized through the practice of feminine writing.

By analyzing the dynamics of identity formation in Roy's novel, this article contributes to the feminist critique (Asl, 2021; Butler, 2004; Mohanty, 2003; West 
\& Zimmerman, 2009) that calls attention to the micropolitics of subjectivity and struggle, as well as an understanding of gender as an attained attribute of situated conduct (Asl, 2018, 2019). In this sense, gender is perceived as "an accomplishment" rather than prescribed psychological and behavioral categories with biological criteria. According to West and Zimmerman, gender is conceived "as an emergent feature of social situations: both as an outcome of and a rationale for various social arrangements and as a means of legitimating one of the most fundamental divisions of society" (1987, p. 126). These divisions function as a restriction to tie socially constructed gender with biological criteria as it does to the two leading characters in the novel, both, of whom are in pursuit of freeing themselves from such restrictions and reconstructing their identity. Hence, the significance of a Cixousian framework is twofold: On the one hand, the notion of inherent bisexuality works as a fundamental concept that encourages the redefinition and reconstruction of socially assigned prescriptions of sex and gender, and on the other, the notion of écriture féminine functions as a platform to reflect on the micro-workings of resistance through inherent bisexuality.

\section{LITERATURE REVIEW}

\section{The Contextual Background: Hijra and its Literary Representation}

Hijra is a unique term used in the Indian subcontinent to refer to the third gender, intersex, and transgender community.
Although hijras have mixed-gender identities, they usually adopt feminine gender roles and adorn themselves with feminine attires. Hence, the word hijra has become an exclusive marker of the identity of transgender women and not of transgender men (Kalra, 2011). The word hijra has thus been embedded specifically into the Indian culture and does not have an equivalent in the Western context, where the term transgender is employed. Although both words have similar meanings, they are underscored by "conflicting readings of transgender identity in India - between third-gendered/hijra [where gender and sex binaries are seen as belonging to an unfamiliar western, Christian framework], and those who identify under the LGBTQ umbrella on the Other" (Mendes \& Lau, 2020, pp. 75-76). The Western definition leans towards the notion of transgenderism as being an individual born as the 'wrong' gender that can be 'fixed' by embodying one particular gender.

In comparison, the notion of hijra represents a new being that is neither a woman nor a man (Dutta \& Roy, 2014; Mount, 2020). Although hijras have always been part and parcel of the social fabric in India, they construct a distinctive subculture that deviates from the mainstream heteronormative culture of Indian society (Agoramoorthy \& Hsu, 2014; Asl, 2020; Hadi \& As1, 2021). Ethnographical studies (Parikh-Chopra, 2018; Rao, 2017; Sibsankar, 2018) reveal that unfavorable social, cultural, and political conditions have pushed this community to the margins 
producing victims of social stigma and discrimination that exacerbate their poverty and illiteracy and restrict employment opportunities.

Hijras' life experiences and the complexity of their identity formation have been translated into literary works. However, the extent of their literary appearances is mostly exclusive to works within the circle of the intended genre. Ramos (2018) states that hijra literature, which delves into the narratives of hijra's experience, is a recent and evolving literary genre in India that focuses on breaking the stereotypical perception of the group. In terms of literary representation, Newport (2018) notes that the traditional works that feature hijra characters have often contextualized their lewd and aggressive representations against economic poverty and hardship. He states that in recent studies on hijra literature, the emphasis has shifted to illustrating the state of transformation between the old and the new ways by implying the inevitable death of traditions that subjugate hijras and placing the hijra community at the center of it. Contemporary portrayals of hijra accentuate the common and personal experiences where such values are embedded into the contextual place and time. Similarly, in Arundhati Roy's TMOUH, individual and collective experiences are interdependent in the identity construction of hijra characters (Mendes \& Lau, 2020; Menozzi, 2019). In this regard, Cixous's subjective explorations of other bisexuality and écriture féminine allow for a more comprehensive understanding of gender identity and self-definition, particularly in making possible the deconstruction of binaries and rewriting of one's destiny. In other words, reconstruction of binaries becomes a process through which the rewriting of self becomes the site of reworking of their life.

\section{The Conceptual Background: Cixous's Inherent Bisexuality and Écriture Féminine}

At the crux of the Cixousian framework is a rejection of biological and essentialist interpretations of sex and gender that allows for a simultaneous embodiment of the masculine and the feminine. As a poststructuralist feminist influenced by psychoanalysis, the primary goal of Cixous is to rewrite heteropatriarchal normativity and dichotomies and underline the existence of subjective "masculine" and "feminine" within selves. In pursuing this focal aim, Cixous has developed the notion of "inherent bisexuality," which provides the basis for the materialization of "écriture féminine" or female writing.

Cixous (1976) defines inherent bisexuality as an abstraction of the self, infused with the production of a desire for permission to embody the masculine and the feminine simultaneously. The term is developed to work as an unorthodox means to unveil the possibilities of gender beyond the liability of physical aspects. Through this concept, the physical attributes are pushed aside to a secondary level as the sexual difference is not measured at "the level of possession or absence of the penis/phallus, 
but at the level of jouissance" (Shiach, 1991, p. 23) or sexual pleasure. Similar to Cixous' concept of inherent bisexuality through which it is an abstraction, jouissance is the "irrepresentable 'other' within the body" (Baitinger, 2019, p. 14), and the unpredictable. As Cixous (1976) explains, inherent bisexuality can be understood as,

variously manifest and insistent according to each person, male or female-of both sexes, nonexclusion either of the difference or one sex and, from this 'selfpermission,' multiplication of the effects of the inscription of desire, over all parts of my body and the other body. (p. 884)

Due to the ambiguous nature of this idea, an individual may facilitate the implications of the masculine and the feminine within themselves and abolish the conventional hierarchy of sexual difference. Cixous does not simplify inherent bisexuality as a "reversal of the binary terms -- by valorising feminine sexuality over the phallic" (Bagchi, 2015 , p. 81). Instead, her notion suggests the potential to navigate the two existing sides and to embrace them as one. Thus, rather than being about the neutrality of gender (neither masculine nor feminine), bisexuality implies a simultaneous existence of both masculine and feminine behavioral traits within a self. According to Cixous, every human being contains the elements of masculine and feminine traits, and that the ability to maintain co-presence within the self is regarded as feminine capacity
(Hall, 2003; Hewson, 2001; Kirkley, 2013; Spanfelner, 2007). In her introduction to bisexuality, Cixous clarifies that this disparity is because male sexuality is hyper-emphasized to almost excluding the female body and desire. She continues that it is rare for men to be able to "exceeds phallic authority, and where the subjectivity inscribing its effects becomes feminine" (2003, p. 43). However, gaining equilibrium of masculinity and femininity is achievable through "self-permission" by resisting phallogocentric language and connecting to the feminine self in the site of writing, regardless of one's sex or/and gender. This variation of the state of bisexuality demonstrates the potential breakthrough of an individual from the binaries of male/ female and masculine/feminine, which are help analyze the characters in Roy's novel.

Additionally, Cixous elaborates that what she calls " feminine' and 'masculine' is the relationship to pleasure, the relationship to spending, because we are born into language, and I cannot do otherwise than to find myself before words; we cannot get rid of them, they are there" (2003, p. 132). Therefore, one can only uncover the layers of possibilities of language through deconstruction and reconstruction by exhausting its potentials and using them to one's advantage. Through writing, language becomes a tool by which discovery and recovery of sexual difference for transgression or/and transformation can be accomplished. Cixous asserts that "writing is the passageway, the entrance, the exit, the dwelling place of the other in me" (1986, 
p. 85). Therefore, the practice of writing is vital as it allows for the realization of the feminine through a redefinition of language. Generally, the purpose of écriture féminine is to invent a feminine way of writing, a language, where patriarchal binary schemes are subverted (Ramshaw, 2003) as writing is predominantly a male tradition imbued with patriarchal ideology.

As Cixous clarifies, écriture féminine's deconstructive role elevates the manifestation of the darker side of the human psyche as a positive force: "her art of living her abysses, of loving them, of making them sing, change, resounding their air with the rhythms of her earth tongues" (2003, p. 59). From Lacanian perspective, the term implies the invalidation of "the idea of desire as negative, founded on lack, separation and death" (p. 22). In other words, écriture féminine views desire as a positive response that brings changes through the valorization of these suppressed elements by validating them as part of the self. It becomes an avenue that honors and glorifies the feminine by creating a space where the multiplication of subjective feminine desires can dismantle patriarchal values and reconnect with the feminine. Cixous's écriture féminine is an approach to writing that highlights fearlessness, unpredictability, and transformation. It comes forth as “"living water', ever-growing and spreading; fearless: for how can the sea be afraid of the land it is blanketing, enveloping?" (Ramshaw, 2003, p. 25). In other words, écriture féminine is a style of writing that is ever-spreading and ever- continuous in its movement, just like 'living water', persistently challenging the limit with its adaptability and flexibility. It ascertains a space that is ever-expansive and can also be associated with the maternal aspects of feminine excess (Farahbakhsh \& Bozorgi, 2013). Cixous stresses that écriture féminine equates feminine subjectivity and abundance to a metaphorical mother, always giving and not barren: "no need for a mother, as long as there is some motherliness: and it is the father, then, who acts the part, who is the mother" (1986, p. 64). In this quote, the father that Cixous refers to is the physical father, and not the concept of the man with his "authority" and "his torment, his desire to be (at) origin" (pp. 64-65). Following this, the rewriting of identity of the characters in the novel can be made possible through their fearlessness to embrace the essence of the $\mathrm{m}$ (other), for it is possible regardless of sex and gender. The characteristic strength of écriture féminine lies in its ability to dismantle patriarchal language and redefine the subjective notions of sex and gender.

\section{MATERIALS AND METHODS}

\section{Research Objectives}

The overall aim of this study is to interrogate the oversimplified representations of hijras as subjugated victims of heteropatriarchal normativity and underline the individuals' active engagement in redefining the established prescriptions of gender and sex instead. Two key objectives are to be pursued in the present study of the selected novel to achieve this focal aim: first, to explore the ways hijra characters challenge and resist 
heteropatriarchal prescriptions of sex and gender; second, to examine the various acts of rewriting, redefining and reasserting the self. The two objectives will help better understand the importance of deconstructing heteropatriarchal prescriptions of sex and gender and reconstructing the self through individual experiences.

\section{Methodology}

The study employs a Cixousian theoretical approach - a poststructuralist feminist perspective - to analyze the novel TMOUH. First, a close reading of the novel examines the fictional representations of hijras' everyday practices of dismantling and reconstructing definitions of self. Hence, the primary method of data collection will be a textual analysis of the novel and the focus of the analysis will be on the two leading characters Anjum and Tilo. The main arguments will be supported with evidence extracted from the novel in accordance to Cixous' theories for a comprehensive analysis of the text-based study.

\section{Material}

Arundhati Roy's The Ministry of Utmost Happiness (2017) recommends itself for this study as its subject matter revolves around sexual and gender non-conformity of characters who want to be neither an "ordinary" man nor an "ordinary woman" (Roy, 2017, p. 18). The novel is widely accepted as a significant contribution to the rising interest in the "hyper (in) visibility" of hijras in India that seek to antagonize the dominant perception of the community as an object of curiosity and underline the normality of their ontological existence instead. It means that for hijras, the state of being, in reality, is not different at a fundamental level but at the very experience that shapes their place within the country. Furthermore, a defining feature of the novel is that even though it is a fictional representation of the community, the characters are "entangled in real, contemporary historical events" (Menozzi, 2019, p. 23). It encompasses the events in Delhi to Kashmir where India and Pakistan wage war for Line of Control, which makes the study's findings rooted in actual historical circumstances.

\section{RESULTS AND DISCUSSIONS}

The discussion focuses on the two characters Anjum and Tilo. It interprets their idiosyncratic approaches in deconstructing and reconstructing prescribed notions of gender and identity through Cixous' inherent bisexuality and écriture féminine.

\section{Resisting Heteropatriarchal Normativities}

Anjum's physical circumstance and her socially prescribed identity as a hijra is a tangible manifestation of the Cixousian notion of inherent bisexuality or other bisexuality. The inherent bisexuality refers to the co-existence of the masculine and the feminine as the necessary condition of Cixous' bisexual model (Cixous, 1976). Anjum can be read as a character that corresponds to both the concept's physical and abstract representations. She 
is explained at the beginning as "a rare example of a Hermaphrodite, with both male and female characteristics, though outwardly, the male characteristics appeared to be more dominant" (Roy, 2017, p. 27). Anjum's appearance leans more towards the male in her youth, but her substantial femaleness may be more apparent in other aspects besides her exterior self. It can be seen through her interest in singing, which is traditionally associated with femininity: "[s] he had a sweet, true singing voice and could pick up a tune after hearing it just once" (p. 19), and she never missed the singing class. For this reason, the expression of her desires can be demonstrated to the real world, not in the singular forms of male/female and masculine/feminine, but the form of hers alone. Anjum belongs to a world outside of humankind's order and hence cannot be subjected to patriarchal normativity by being in this position.

Anjum's biological condition as having both male and female sexual parts makes her a perfect example of the inherent bisexuality. Even though the concept of sexual difference that Cixous reflects on is not of anatomical differences but morphological ones, she acknowledges that limiting thinking through sexual difference (i.e. 'man' and 'woman') is inevitable (Farahbakhsh \& Bozorgi, 2013). Because of this, Anjum's exclusion from the categorization serves as an advantage from Cixous' standpoint. As a Cixousian bisexual, her identity is shaped through her corporeal experience, which is unique to herself and not generalizable to any sex and/or gender. However, due to the growing need to attain a female exterior, the presence of her male genitalia creates a conflict in her character. It was largely an issue of the physical aspect of which she is aware from the beginning-i.e., when she was still called by her male birth name, Aftab, and she sees a hijra from the balcony of his home, which attracts her interest. Anjum decides to follow her for she is the closest to whom Anjum desires to be: "The woman Aftab followed could only dress as she was dressed and walk the way she did because she was not a woman. Whatever she was, Aftab wanted to be her" (Roy, 2017, p. 30). Here, Anjum demonstrates a contradiction to her acknowledgment of a 'woman' by viewing the stranger as a woman who is not a woman, but a person, someone who dresses as a woman the way Anjum herself desires to become. While the existence of such persona is not aligned with the conventions of gender and sex as being neither men nor women, it helps to clarify Anjum's interpretation of identity.

Anjum expresses fear for a male body and a longing for a body that is not a male but close to anything a woman can be. In other words, she desires to embrace a new identity as a hijra and forsake the male identity she was born with. The reality of puberty is complicated for Anjum for "he developed an Adam's apple that bobbed up and down [...] his voice broke. A deep, powerful man's voice appeared in place of his sweet, high voice" (Roy, 2017, p. 38). Feeling betrayed by her own body, "he grew quiet, and would speak only as a last resort [...] he stopped singing" (p. 38). Later, after 
she transitioned from a male to a hijra, while her voice "frightened other people [...] it did not frighten its owner in the way her God-given one had" (p. 46). To subdue the turmoil that she experiences, Anjum starts grooming herself with feminine attire to accentuate her handsome features and "[her] outrageous kind of femininity" (p. 42) once she begins living as a hijra at Khwabgah. By embodying the other bisexuality, "she does not annihilate differences but cheers them on, pursues them" (Cixous, 1986, p. 85). As emphasized in the novel, it is the inherent femaleness that she wants to transcribe into her body and not merely her "girl-part that was just an appendage" (p. 31). Hence, her girl-part serves only as an attribute that connects to the more predominant accumulated feminine desires inside her to embody the feminine.

However, the novel's issues of sex and gender arise mainly due to a pattern of established binaries. The novel initiates a prominent conflict about Anjum's gender identity from the beginning when her mother, Jahanara Begum, named her Aftab, later dreadfully realizing that Anjum owns both the boy-part and the girl-part. Jahanara's inability to consider sex and gender outside the language barrier is the root of this problem. Cixous states that we could impose changes to the language, but it "would become just as closed, just as immobile and petrifying as the words 'masculine' and 'feminine' and would lay down the law to us" (2003, p. 132). During the earlier phase of her life, Anjum's identity is constructed within the limitation of language used by the people around her. When she is born, the midwife states that Anjum is a male baby. Driven by logocentrism, this fear develops because the only language Jahanara knows-i.e., Urdu-abides by the rule that "all things, not just living things...carpets, clothes, books, pens, musical instruments...[have] a gender" (Roy, 2017, p. 13).

Even though there are words to describe Anjum-Hijra, and Kinnar [the term for hijras in north India], for example - she deduces that "two words do not make a language" (Roy, 2017, p. 14). In this case, Urdu limits Jahanara's perception of the world and denies her the potentials that can be realized outside of the language. Because of this, she fails to detach her situation from the language, which affects Anjum's childhood. Hence, the existing binaries in language are more likely to be detrimental as she cannot adapt to these standards of sex and gender. Failure to resist this condition results in the formation of a self that is continually confined by patriarchal reasoning. Anjum's biological father, Mulaqat Ali, is an example of a community constrained by the traditional structure of language, which is embedded within him that he fails to liberate himself. Hence, while Mulaqat Ali's dependence on language may provide strength, it can also disrupt any means to extract and emancipate oneself. The main reason for Mulaqat Ali's shortcoming is his belief that "everything that happened had happened before. That it had already been written, sung, commented upon and entered into history's inventory. 
That nothing new was possible" (p. 25). As a result, he remains a conventional character ruled by patriarchy molded by the law of language, which cannot open himself to Cixous's concept of other bisexuality.

In contrast to her parents, Anjum can liberate herself from the heteronormative fetters of language and reconcile with her masculine and feminine self. As she materializes the feminine through conscious efforts of resisting the patriarchal structure of language, Anjum can be regarded as a bisexual model from the Cixousian perspective. For instance, when she hears the love story of Laila and Majnun, she says, "I'm all of them, I'm Romi and Juli, I'm Laila and Majnu. And Mujna, why not? Who says my name is Anjum? I'm not Anjum, I'm Anjuman. I'm a mehfil, I'm a gathering. Of everybody and nobody, of everything and nothing" (p. 8). Here, when she disregards the existing rules by challenging the relationship between language and herself, she asserts a selfassurance by blurring the boundary of fixed meanings in language-i.e., being 'everybody and nobody' and 'everything and nothing'. Anjum adheres to Cixous' emphasis that because one cannot get rid of language, the only thing one can do is to use and exhaust it to benefit one's position (Kimmey, 2003). In this relation, Anjum does not subscribe to phallogocentrism but affirms a novel and authentic pleasure of what Cixous calls 'spending' the language or using language in whichever way she sees fit. Anjum places herself at the heart of it and makes it hers, and in so doing, emancipates herself from phallogocentrism of language.
Another central character who resists heteropatriarchal discourses is a woman named Tilo, who similarly embodies Cixous's ideal of inherent bisexuality. Cixous states that bisexuality is "a fantasy of a complete being, which replaces the fear of castration and veils sexual difference insofar as this is perceived as the mark of a mythical separation" (1986, p. 84). This "fantasy of a complete being," is then manifested into reality, through which the state of bisexuality is successfully embodied. When Tilo is introduced in the novel through her male friend Biplap's narration, she is depicted as neither a woman nor a man. As we are told, Tilo "wore no make-up and did nothing---none of those delightful things girls do [...] she had a way of standing, with her weight on the balls of her feet, her shoulders squared, that was almost masculine, and yet wasn't" (Roy, 2017, p. 232). Even her way of dressing and mannerism reflect her essentially peculiar self. On different occasions, she wears "a printed, oversized man's shirt that didn't seem to belong to her" (p. 233), or "a purple sari and a black-and-white-checked blouse, a shirt actually [...] her hair...short enough for it to look spiky" (p. 285). In terms of her mannerism, there is "complete absence of a desire to please, or to put someone at ease" (p. 234). She has a "haughtiness" that "had to do with the way she lived, in the country of her own skin" (p. 327).

In addition, Tilo embodies a presence that is free of the rules and the laws of the world, a self that is not bound by the existing patriarchal structure but is existing 
within the realm of reality at the same time. It became evident when "she gave the impression that she had somehow slipped off her leash. As though she was taking herself for a walk while the rest of us were being walked-like pets" (Roy, 2017, p. 234). These instances show Tilo's high confidence and certainty, typical of a liberated self that does not align with patriarchal standards. Ultimately, the image created from these various traits is novel, making Tilo a character who cannot be pinned down to stereotypical feminine and masculine characters. Hence, she manifests Cixous's inherent bisexuality with the ambiguity in representing herself to others.

In addition, Tilo is depicted as a highly independent woman unaffected by the norms and in a state of rewriting her life, which adheres to Cixous's écriture féminine. The theory emphasizes a place, somewhere else, where there is an escape from the doomed repetition of patriarchal binaries and where writing enables dreams and the creation of new worlds (Cixous, 1986). From this perspective, Tilo is a typical Cixousian woman as she construes living not through the lens of the existing world but one that is hers alone. Among the most prominent examples are her personal views about family and marriage. From early on, and while she has a mother, Tilo's life prevents her from belonging to the ordinary family as she is "a girl who didn't seem to have a past, a family, a community, a people, or even a home" (Roy, 2017, p. 236). It is most likely due to the peculiar nature of her relationship with her mother, between whom abandonment has become the first tangible relation. It is revealed that "her mother was indeed her real mother, but had first abandoned her and then adopted her" (p. 235).

However, because she is not attached to the traditional idea of a family, Tilo favors finding and inventing a distinctive approach to connect to different people outside of the norms. It is also due to the lack of knowledge of her roots that result in Tilo's "individuality, her quirkiness and unusualness" (Roy, 2017, p. 362). She remains single as "she wanted to be free to die irresponsibly, without notice and for no reason" (p. 242). Here, Tilo displays her strong desire not to be tied to marital laws and regulations in shaping her life's destiny. Following this, her decision for abortion when she becomes pregnant is driven by the primal desire to avoid inflicting her recklessness by birthing her child into the time of war and into a time when she cannot provide for the child. She disassociates the decision from the men in her life-Naga, her husband, and Musa, the father of the aborted child - as it "had nothing to do with her feelings for Naga or her love for Musa" but because "she did not wish to inflict herself on a child. And she did not wish to inflict a replication of herself on the world" (p. 584) as did her mother, Maryam, to her. This action is customarily viewed as taboo, but Tilo has used it to enable her to establish control in the face of predetermined destiny. In this way, Tilo rewrites her fate by defying the societal conventions of family and marriage with her views and actions. In 
remaining indifferent to patriarchy and true to herself, she materializes the writing of her story.

\section{Redefinition of the Self}

Having rejected heteropatriarchal values, both Anjum and Tilo attempt to forge a new truth for their selves by writing an alternate progression of their stories. For Anjum, her search begins when she meets other hijras living at Khwabgah or the House of Dreams. Initially, she did not know of the existence of hijras. During this phase of her life, when she learns about the community, she is given a chance to question and embrace the term as part of her authentic self. Because she is restricted within her own space at home, she finds solace in the space of Khwabgah, where she feels most validated by the existence of other people similar to herself: "it was the only place in his world where he felt the air made way for him" (Roy, 2017, p. 31). Despite the condition of the house that is "ordinary, broken-down," Anjum experiences it "as though he were walking through the gates of paradise" (p. 32). When Anjum frequents this place, she is already at the start of her journey of rewriting her life to realize a potential fulfillment of the self. Subsequently, the body modification that follows later comes as a requirement to verify this desire. In other words, Anjum can rewrite her predestined fate by altering the body given to her to come closer to finding her true self.

Additionally, Cixous's écriture féminine can be deeply utilized in understanding and interpreting Anjum's biggest desire and motivation in TMOUH to be a mother. Cixous (1991) speaks of the nurture and kindness of a mother to an all-encompassing form of love. From her perspective, a mother has always been associated with "the other," m(other): "she who kills no one in herself, she who gives (herself) her own lives: a woman, is always in a certain way "mother" for herself and the Other" (Cixous, 1991, p. 50). Being a mother may be regarded as the pinnacle of Anjum's happiness in life, the final and conclusive condition that would perhaps complete and set herself at peace. She has first established this when she welcomes Zainab, a foster child, into her life: "she wanted to be a mother, to wake up in her own home, dress Zainab in a school uniform..." (Roy, 2017, p. 47). She has also loved Zainab strongly as any mother does her child: “Zainab was Anjum's only love” (p. 47). Cixous' écriture féminine is an approach that emphasizes the abundance of feminine desires and validates them as positive forces (Farahbakhsh \& Bozorgi, 2013). Based on this, Anjum's decision can be viewed as a result of accumulation and acceptance of her desires to own her identity as a woman and a mother. The presence of the child appeases the war within Anjum that an inhabitant of Khwabgah, Nimmo Gorakhpuri, has referred to as the war 'Indo-Pak' and triggers Anjum's instinctual feminine capacity: “... the tiny creature subdued (for a moment at least) what Nimmo Gorakhpuri had so astutely and so long ago called Indo-Pak [...] Her body felt like a generous host instead of a battlefield" (Roy, 2017, p. 48). 
Here, the initial doubts and conflicts of self have washed away the moment Anjum is given the smallest experience of something inherently motherly.

Furthermore, along the process of 'becoming' a mother, Anjum rewrites the stories of her life in the name of love. Her love and desire can be translated through the Cixousian notion of écriture féminine as a style that is ever-spreading as much as it is fearless and whimsical (Ramshaw, 2003). Anjum demonstrates a state of certainty and capacity for love towards Zainab: "she was caught unawares by the fact that it was possible for one human being to love another so much and so completely" (Roy, 2017, p. 50). She then instills the act of rewriting in the stories that she tells Zainab as a bedtime story which involves transforming them in the process for the sincerity and pleasure of love for another being. The novel illustrates that "in order to please Zainab, Anjum began to rewrite a simpler, happier life for herself. The rewriting, in turn, began to make Anjum a simpler, happier person" (p. 54). While the rewriting of her life that Anjum incorporated is tempered to make the bedtime stories childproofed, there is an element of truth. Anjum's storytelling is grounded with the need to "transfuse herself into Zainab's memory and consciousness, to reveal herself without artifice, so that they could belong to each other completely" ( $p$. 51). This narration adheres to the very idea of écriture féminine that acknowledges feminine capacity as inexhaustible, allencompassing, and all-consuming. Hence, the writing and rewriting of Anjum's life in her stories correlate with the motherly love for a child that she intends to translate as being an essence of her self-imbued into her child.

In addition, it is necessary to highlight Anjum's perseverance in finding and establishing a self or identity through feminine writing. As stated, the condition for Anjum to possibly reach her ultimate destiny is by becoming a mother, a state that completes the identity and self she fights for. It is exhibited by the utter faith in her and her destined fate: "I was born to be a mother [...] Just watch. One day Allah Mian will give me my own child. That much I know" (Roy, 2017, p. 130). In this relation, écriture féminine is used to redefine the subjective notions of sex and gender by dismantling patriarchal language and infusing one's truth (Ramshaw, 2003). The word mother, which is traditionally associated with woman is subverted by Anjum's insistence on the nuance it carries, which in turn creates a new avenue for embodying the genuine essence of 'mother.' For instance, it becomes apparent in a later incident through an abandoned child that Anjum's definition of mother is not predetermined by its constructed meaning, but is characterized by an instinctive sense of fierce love and protectiveness. In exchange, those feelings serve to solidify Anjum's true purpose: "there was something unleashed about her, something uncalibrated and yet absolutely certain---a sense of destiny perhaps," and to tame her: "she's a gift from God. Give her to me. I can give her the love she needs" (pp. 183-184). While the child has 
awakened Anjum's ferocious desire to fight for instinctual love, the child also settles into Anjum's life as a physical form of solace and fulfillment of her destiny. Therefore, the rewriting of Anjum's self is made possible by the persistence to establish her identity.

Similarly, Tilo weaves her story through the metaphorical act of rewriting her identity as a mother. In contrast to Anjum, Tilo's journey to realize her identity as a mother is a deliberate process. While she decides to have an abortion when she finds her unwanted pregnancy as a hindrance to her current situation, she later reclaims and embodies the identity of a woman and a mother by adopting a child that is not her own. As we are told, "she had no idea why she of all people, who never wanted children, had picked up the baby and run" (Roy, 2017, p. 388). The instinctive act of taking a parentless baby under her care just after the voluntary termination of her pregnancy can be translated into an act of rewriting her life. As suggested in the narration, "her part in the story had been written. But not by her [...] Someone" (p. 388). It implies a shift in her and her destiny. Regardless of how or by whom Tilo's story is rewritten, it's implication adheres to Cixous's écriture féminine that honors the overflowing of love in all of its unpredictability and fearlessness. Change is necessarily an element that brings forth her new destiny and reshapes her story based on her love for a child. The statement that comes after is a reflection of this event, "If you like, you can change every inch of me. I'm just a story" (p. 388). It alludes to the nature of a self that is always changeable as a story is. In other words, it means to place Tilo's life as the site of writing and rewriting of the self in a sense that resembles the writing and rewriting of a story and that the liberty of the act is dependent upon anyone and anything. Here, Tilo's situation resonates with what Cixous emphasizes as the possibility that "the crucial scene had been set up [for me] in a previous story, outside [me], outside the room. Thus, [what I took for] the beginning was nothing but the final revelation" (Cixous, 2003, p. 73). It can be equated as a metaphorical representation of Tilo's rewriting of destiny to re-characterize her identity as a mother, through which her story is rewritten upon the arrival of the parentless baby.

The act of writing in Tilo's life sanctions the formulation of identity as a mother and a daughter. Écriture Féminine has always been associated with a woman's relationship to "motherhood" (Cixous, 1991), of the generosity of love she instills into her child. Since the beginning, Tilo has had a problematic relationship with her mother, Maryam Ipe, due to the latter's refusal to acknowledge Tilo as her real daughter publicly. From an outsider perspective like her husband's, Maryam has made a reasonable decision, because "for a young woman who belonged to a traditional community to have chosen a life of independence, chosen to eschew marriage in order to claim a child born to her out of wedlock [...] was an act of immense love" (Roy, 2017, p. 361). However, Tilo remains 
unforgiving until after Maryam's death and when Tilo has her adopted daughter. Near the end of the novel, Tilo brings forth her late mother's ashes in a small pot to be buried in the graveyard: "The church had refused to bury her mother, so any prayers would do" (p. 615). It is a way of parting between a daughter and a mother she has grown to resent but has now been forgiven and put to rest. That the realization dawns on her come at the cost of embracing her own rewritten identity as a woman and a mother in the time of war. The war, which can be a literal and/or metaphorical representation, has reshaped and instilled into Tilo a newly fathomed expression of self and identity. As highlighted, "she had never understood why her mother [...] loved this manly, soldierly, warlike passage. But she had. When Tilo opened her eyes [...] she was weeping" (p. 617). This realization marks the loss as the birth of a new self where the barest essence of feminine desire is understood, forging an intimate connection where a profound understanding is reached between a woman and another woman. Thus, it subverts the association of desire with separation and death found in a Lacanian perspective. Meanwhile, it elevates Cixous's écriture féminine that outlines it as perhaps the most "violently real" and "faithfully natural" force (Ramshaw, 2003, p. 26). In this manner, the redefinition of Tilo's self and identity is achieved through the comprehension and rewriting of the meaning of a daughter and a mother, to see that being a mother is not selfish but an immense act of courage and love.

\section{CONCLUSION}

This study employed Hélène Cixous's notions of other bisexuality and écriture féminine to examine the complex nuances of hijras or intersexes' identity formation in Arundhati Roy's TMOUH. The analysis focused on Anjum and Tilo's individual struggles to interrogate heteropatriarchal prescriptions and reconstruct a new definition of the self. Both characters resist against the existing sex and gender binaries in the Indian culture. Anjum liberates herself from the restricting and excluding binaries in Urdu language and exploits it to her own advantage. In a like manner, Tilo's embracing of feminine desires allows her to reassess and reconstruct her identity without being subjected to the imposed static binaries. In this regard, the rewriting of self and identity is made possible through a conscious realization of the subjective feminine experiences. Anjum's and Tilo's individual struggles against established norms provides unique insight into the more subjective and personalized experiences that come with experiences of loss, separation, and death. While these notions are often characterized as negative, they permit the realization of the barest desires and reassign them as positive and essential forces in reconstructing one's sense of self. In embracing their identity as a hijra/ woman and a mother, both characters go through a continuous process of writing and rewriting. The identity shifts are justified through Cixous's écriture féminine which considers the transformations as the necessary condition to the feminine excess 
as well as to their liberation of their selves from a fixed condition of socially construct gender identity. In spite of predetermined fate, the alternatives that are writing and rewriting of destiny taken to respond to it form the characters' identity. Though Anjum does not have the biological criteria to become a mother, she defines her identity through a capacity of fierce and protective love for children. Likewise, Tilo's identity as a woman and a mother is achieved through understanding, acceptance, and compensation of motherly love. In this manner, both Anjum and Tilo illustrate that the identity of a hijra/woman and a mother is not predetermined by sex and gender but is formulated in a complex process of conscious rewriting of the self.

\section{ACKNOWLEDGEMENT}

The authors are thankful to the anonymous reviewers from the Pertanika Journal of Social Science and Humanities for their detailed comments and suggestions.

\section{REFERENCES}

Agoramoorthy, G., \& Hsu, M. J. (2014). Living on the societal edge: India's transgender realities. Journal of Religion and Health, 54(4), 14511459. https://doi.org/10.1007/s10943-0149987-z

Asl, M. P. (2018). Fabrication of a desired truth: the oblivion of a Naxalite woman in Jhumpa Lahiri's The Lowland. Asian Ethnicity, 19(3), 383-401. https://doi.org/10.1080/14631369.2018.1429892

Asl, M. P. (2019). Foucauldian rituals of justice and conduct in Zainab Salbi's Between Two Worlds.
Journal of Contemporary Iraq \& the Arab World, 13(2-3), 227-242. https://doi.org/10.1386/ jciaw_00010_1

Asl, M. P. (2020). Micro-physics of discipline: Spaces of the self in Middle Eastern women life writings. International Journal of Arabic-English Studies, 20(2), 223-240. https://doi.org/10.33806/ ijaes2000.20.2.12

Asl, M. P. (2021). Gender, space and counter-conduct: Iranian women's heterotopic imaginations in Ramita Navai's City of Lies. Gender, Place \& Culture. https://doi.org/10.1080/096636 9X.2021.1975100

Bagchi, R. (2015). Where poetry tends towards the philosophical: Hélène Cixous's gift of feminine writing. A Journal of Interdisciplinary Studies, 1(2), 77-92.

Baitinger, F. C. (2019). The subject of Jouissance: The late Lacan and gender and queer theories [Doctoral dissertation, City University of New York]. CUNY Academic Works. https:// academicworks.cuny.edu/gc_etds/3243

Blades, S. E. (2009). The feminine erotic and gen(d) re bending: Ambiguity and sexual androgyny in Virginia Woolf's Orlando [Doctoral dissertation, The University of North Carolina]. ProQuest Dissertations Publishing. https://search.proquest. com/openview/26bf49726b92f1e7ecf8a0a016 $\mathrm{b} 4 \mathrm{~d} 5 \mathrm{fd} / 1$ ?pq-origsite $=$ gscholar $\& \mathrm{cbl}=18750 \&$ $\operatorname{diss}=y$

Butler, J. (2004). Undoing gender. Routledge.

Cixous, H. (1976). The laugh of the Medusa. Signs: Journal of Women in Culture and Society, 1(4), 875-893. https://doi.org/10.1086/493306

Cixous, H. (1981). Castration or decapitation? (A. Khun, Trans.). Signs, 7(1), 41-55.

Cixous, H. (1986). The newly born woman (B. Wing, Trans.). I.B. Tauris \& Co. (Original work published 1975). 
Cixous, H. (1991). Coming to writing and other essays (S. Cornell, D. Jenson, A. Liddle, \& S. Sellers, Trans.). Harvard University Press.

Cixous, H. (2003). Preface. In S. Sellers (Ed.), The Hélène Cixous reader (pp. xv-xxiii). Routledge. https://doi.org/10.4324/9780203408483

Dutta, A., \& Roy, R. (2014). Decolonizing transgender in India: Some reflections. Transgender Studies Quarterly, 1(3), 320-337. https://doi. org/10.1215/23289252-2685615

Farahbakhsh, A., \& Bozorgi, S. (2013). The Cixousian woman in Jhumpa Lahiri's 'The Treatment of Bibi Haldar'. Journal of Language, Literature and Culture, 60(2), 118-13. https://doi.org/10.1 179/2051285613Z.0000000009

Hadi, N. H. A., \& Asl, M. P. (2021). The objectifying gaze: A Lacanian reading of Viet Thanh Nguyen's The Refugees. GEMA Online ${ }^{\circledR}$ Journal of Language Studies, 21(1), 62-75. https://doi. org/10.17576/gema-2021-2101-04

Hall, E. B. (2003). Textual tensions: Reading (with) Hélène Cixous. University of WisconsinMadison.

Hewson, M. A. (2001). The male writer and the feminine text: Hemingway's major novels from a Cixousian perspective [Doctoral dissertation, University of Ottawa]. https://doi.org/10.20381/ ruor-16173

Hoctor, K. E. (2013). “White ink”: The body and écriture féminine in Toni Morrison's Beloved [Master's thesis, DePaul University]. The Institutional Repository at DePaul University. https://via.library.depaul.edu/etd/151

Hossain, A. (2012). Beyond emasculation: Being Muslim and becoming hijra in South Asia. Asian Studies Review, 36(4), 495-513. https://doi.org/1 $0.1080 / 10357823.2012 .739994$

Iesar, A. (2019). The politics of canons, identity and representation: A study of the counter canonical discourse strategies in Arundhati Roy's novel
The Ministry of Utmost Happiness. Advances in Language and Literary Studies, 10(2), 49-55. https://doi.org/10.7575/aiac.alls.v.10n.2p.49

Islam, R. (2020). Exploring identity and space of Hijra: Arundhati Roy's The Ministry of Utmost Happiness. Journal of Asian and African Social Science and Humanities, 6(1), 26-38.

Kalra, G. (2011). Hijras: The unique transgender culture of India. International Journal of Culture and Mental Health, 5(2), 121-126. https://doi.or g/10.1080/17542863.2011.570915

Kimmey, D. A. (2003). Queer pleasures in writing: Transgressive intimacy and the play of sexual difference in Hélène Cixous's "The Book of Promethea" [Master's thesis, University Chicago]. ProQuest Dissertations Publishing. https://www.proquest.com/openview/f66b1344 $5 \mathrm{~d} 52448 \mathrm{a} 40 \mathrm{f5e} 124080331 \mathrm{dc} / 1$ ?pq-origsite $=\mathrm{gs}$ cholar\&cbl $=18750 \&$ diss $=\mathrm{y}$

Kirkley, L. (2013). Hélène Cixous's autre bisexualitéand the eternal feminine in the works of Nuala Ní Dhomhnaill. Women: A Cultural Review, 24(4), 315-336. https://doi.org/10.1080 /09574042.2013.857964

Lau, L., \& Mendes, A. C. (2019). Romancing the other: Arundhati Roy's The Ministry of Utmost Happiness. The Journal of Commonwealth Literature, 1-16. https://doi. org/10.1177/0021989418820701

Mendes, A. C., \& Lau, L. (2020). The precarious lives of India's Others: The creativity of precarity in Arundhati Roy's The Ministry of Utmost Happiness. Journal of Postcolonial Writing, 56(1), 70-82. https://doi.org/10.1080/1744985 5.2019 .1683758

Menozzi, F. (2019). "Too much blood for good literature": Arundhati Roy's The Ministry of Utmost Happiness and the question of realism. Journal of Postcolonial Writing, 55(1), 20-33. https://oi.org/10.1080/17449855.2018.1507919 
Mohanty, C. T. (2003). "Under Western Eyes" revisited: Feminist solidarity through anticapitalist struggles. Signs: Journal of Women in Culture and Society, 28(2), 499-535. https:// doi.org/10.1086/342914

Mount, L. (2020). "I am not a Hijra": Class, respectability, and the emergence of the "New" transgender woman in India. Gender \& Society, 34(4), 620-647. https://doi. org/10.1177/0891243220932275

Newport, S. (2018). Writing otherness: Uses of history and mythology in constructing literary representations of India's Hijras [Doctoral thesis, University of Manchester]. https://www.research. manchester.ac.uk/portal/files/75066695/FULL_ TEXT.PDF.

Parikh-Chopra, S. (2018). Transgender minority stress and mental health outcomes among Hijras in India [Doctoral dissertation, The Chicago School of Professional Psychology]. ProQuest Dissertations Publishing. https://search.proquest. com/openview/c08cf7eb7d44ac3e6bcaf5da8b $\mathrm{d} 73 \mathrm{bb3} / 1$ ?pq-origsite $=$ gscholar $\& \mathrm{cbl}=18750 \&$ diss $=y$.

Ramos, R. C. (2018). The voice of an Indian trans woman: A Hijra autobiography. Indialogs: Spanish Journal of India Studies, 5, 71-88. https://doi.org/10.5565/rev/indialogs.110
Ramshaw, S. (2003). Nearing the 'Wild Heart': The Cixousian 'feminine' and the quest for law's origin. Australian Feminist Law Journal, 19(1), 11-27. https://doi.org/10.1080/13200968.2003 .10854312

Rao, M. (2017). Troubling suicide: Law, medicine and Hijra suicides in India [Doctoral dissertation, University of Toronto]. ProQuest Dissertations Publishing. https://www.proquest.com/ openview/d73295a591ac9dc2029a2a82bbf320 $63 / 1$ ?pq-origsite $=$ gscholar $\&$ cbl $=18750$

Roy, A. (2017). The ministry of utmost happiness. Random House.

Shiach, M. (1991). Hélène Cixous: A politics of writing. Routledge.

Sibsankar, M. (2018). The Hijras of India: A marginal community with paradox sexual identity. Indian Journal of Social Psychiatry; Mumbai, 34(1), 79-85. https://doi.org/10.4103/ijsp.ijsp_21_17

Spanfelner, D. (2007). Hélène Cixous: A space for the other. In between forgetting, remembering and rewriting [Doctoral thesis]. State University of New York.

West, C., \& Zimmerman, D. H. (1987). Doing gender. Gender \& Society, 1(2), 125-151.

West, C., \& Zimmerman, D. H. (2009). Accounting for doing gender. Gender \& Society, 23(1), 112122. https://doi.org/10.1177/0891243208326529 